\title{
MEDICINE
}

\section{RESULTS OF SURGICAL TREATMENT OF CALCANEAL FRACTURES IN PATIENTS WITH DIABETES MELLITUS}

\author{
${ }^{I}$ Kovalchuk P. Ye., PhD in traumatology, Assoc. Professor, Department of Traumatology and \\ Orthopedics \\ ${ }^{l}$ Gasko M. V., PhD in traumatology, Assoc. Professor, Department of Traumatology and Orthopedics \\ ${ }^{I}$ Tulyulyuk S. V., Assistant Department of Traumatology and Orthopedics \\ ${ }^{l}$ ShutkaV.J., MD, PhD, Assoc. Professor, Department of Urology and Neurosurgery \\ ${ }^{2}$ Bugai R. I., Doctor orthopedist traumatologist,
}

${ }^{1}$ Higher education institution in Ukraine «Bukovinian State Medical University», Ukraine.

${ }^{2}$ Emergency hospital of Chernivtsi, Ukraine

DOI: https://doi.org/10.31435/rsglobal_ws/30042019/6469

\section{ARTICLE INFO}

Received: 15 February 2019

Accepted: 20 April 2019

Published: 30 April 2019

\section{KEYWORDS}

Calcaneal fracture, minor invasive osteosynthesis, bone osteosynthesis, diabetes mellitus, diabetic foot syndrome, calcaneal fracture consequences.

\begin{abstract}
One of the complicated problems of traumatology in the treatment of patients with calcaneal fractures is prevention of diabetes mellitus consequences. The work presents the analysis of treatment results of 72 patients with calcaneal fractures treated by means of surgical method at the Traumatological Adult Department, of the Regional Clinical Hospital "Emergency Rescue Hospital" (ERH), Chernivtsi, for the period from 2011 to 2018 . With the purpose to examine the efficacy of treatment of calcaneal fractures all the patients were distributed into three clinical groups, patients with diabetes mellitus were isolated, and remote results of treatment were compared. Therefore, analysis of surgical treatment remote results of intra-articular calcaneal fractures in patients suffering from diabetes mellitus demonstrated that application of closed reposition under electrical optical transducer (EOT) control and fixation by means of wires leads to $44,38 \%$ improvement of treatment results, shortened terms of inability-to-work and disability.
\end{abstract}

Citation: Kovalchuk P. Ye., Gasko M. V., Tulyulyuk S. V., ShutkaV. J., Bugai R. I. (2019) Results of Surgical Treatment of Calcaneal Fractures in Patients with Diabetes Mellitus. World Science. 4(44), Vol.2. doi: 10.31435/rsglobal_ws/30042019/6469

Copyright: (C) 2019 Kovalchuk P. Ye., Gasko M. V., Tulyulyuk S. V., ShutkaV. J., Bugai R. I. This is an open-access article distributed under the terms of the Creative Commons Attribution License (CC BY). The use, distribution or reproduction in other forums is permitted, provided the original author(s) or licensor are credited and that the original publication in this journal is cited, in accordance with accepted academic practice. No use, distribution or reproduction is permitted which does not comply with these terms.

Introduction. Damages of the calcaneal bone results in anatomical changes and disorders of biomechanics of movements. Although in recent years the problem of such damages has not been adequately reported in literature [1,58-59; 2, 58-59].

Among tarsal bones fractures of the calcaneal bone are found most frequently. In the structure of fractures of the muscular-skeletal system according to the data of different authors their part constitutes from $2 \%$ to $6 \%$ and $60 \%$ among all the fractures of tarsal bones [3, 329-331; 4, 329-331]. In spite of this fact, orthopaedists-traumatologists have not formed a universal approach to classification, diagnostics and treatment of calcaneal fractures. Depending on the mechanism of injury calcaneal fractures are divided into 2 main types: extra-articular $-25 \%$ of all fractures and intra-articular $-75 \%[5,70-75 ; 6,1615-1622]$. 
Intra-articular fractures provoke the biggest number of complications. Post-traumatic deformity of the subtalar joint results in deforming arthrosis, compression tenosynovitis of the fibular muscle tendons, trophic changes of the soft tissues [6, 1615-1622].

One of the most topical issues in traumatology is treatment of patients with calcaneal fractures and diagnosed diabetes mellitus. Comorbidity of changes of the nervous system, arterial and microcirculatory flow, osseous-articular apparatus occupy a special place among them [7, 2-10].

Diabetes mellitus (DM) is one of the topical issues of the health care systems in all the countries of the world without exception. Nowadays the WHO estimates approximately 387 millions of DM patients which constitute over $8 \%$ of the global population, at the same time, about $50 \%$ involves the most active and able-to-work age - from 40 to 59. Considering the rates of this disease the World Diabetic Federation experts prognosticate that the number of DM patients in 2030 will be 1,5 times as much and will be 552 million people $[8,143-165 ; 9,50]$.

Timely detection of DM patients by means of determining glycated hemoglobin, the degree of the risk of occurring complications and giving a comprehensive aid will enable to prevent possible complications, improve the quality of treatment and make the terms of inability-to-work shorter.

Objective: to publish the results of surgical treatment of calcaneal fractures in patients with diabetes mellitus.

Materials and methods. 72 patients with calcaneal fractures undergoing surgery were treated during the period from 2011 to 2018 at the Traumatological Department, of the Regional Clinical Hospital "Emergency Rescue Hospital" (ERH), Chernivtsi.

On admission all $72(100 \%)$ patients were examined for blood sugar (normal level is from 3,5 to $5,5 \mathrm{mmol} / \mathrm{L}$ ). The test was made on empty stomach in the biochemical laboratory of ERH. Additional blood test for glycated hemoglobin ( $\mathrm{HbAlc}$ ) was made for all the patients with glucose level in the blood $\geq$ $5,5 \mathrm{mmol} / \mathrm{L}$. The normal $\mathrm{HbAlc}$ level ranges within $4-6,5 \%$ out of the total amount of hemoglobin. Patients with higher glucose level in the blood were consulted by the endocrinologist, and type II diabetes mellitus with various degree of severity was verified. Individual correcting therapy without insulin administration and strict keeping to diet № 9 were indicated for all the patients.

With the purpose to study the efficacy of treatment of individuals with calcaneal fractures in DM patients all of them were distributed into three clinical groups.

The first group included $21(29,16 \%)$ individuals with extra-articular calcaneal fractures undergoing surgery with the use of screws. By the results of examination of glucose level in the blood and anamnesis data, $5(23,80 \%)$ patients from this group suffered from DM (in 2 patients - first determined).

The second group included $32(44,44 \%)$ patients with intra-articular calcaneal fractures undergoing closed reposition under EOT-control and fixation by means of wires. $6(18,75 \%)$ patients of this group were afflicted with DM (in 1 patient - first determined).

The third group included $19(26,40 \%)$ patients with intra-articular calcaneal fractures undergoing open reposition and osteosynthesis by means of plates and screws. 4 (21,05\%) patients suffered from DM (in 1 patients - first determined).

An average age of patients was 37,5 ranging from 19 to 67 . Men constituted the majority -61 $(84,72 \%)$. At the same time, able-to-work men constituted the major part - $54(88,52 \%)$ patients. Analysis of causes of calcaneal fractures showed that in the majority of cases the injury was caused by falling from the height $-62(88,88 \%)$ and road accidents - $10(11,12 \%)$ patients.

In all the clinical groups the treatment of patients began with anti-edematous therapy, elevated position of the lower limb and treatment of comorbid diseases. Surgery was performed on the 9-11 day after admission. The criteria to choose the method of osteosynthesis were age of patients, comorbid diseases and phlyctena available, the number of intra-articular fragments by Sanders classification.

Fractures of the calcaneal bone tuber occurred mainly among the patients of the first clinical group. The treatment of such patients was performed by means of closed or open reposition and fixation of fragments by two screws, wires and 8-like wire loop. In the postoperative period the limb was immobilized by means of plaster splint to remove sutures, followed by active and passive movements in the ankle joint. Graduated weight bearing on the limb was allowed in 8 weeks, and a complete one - in 10-12 weeks.

The patients from the $2^{\text {nd }}$ clinical group underwent closed reposition of fracture and fixation by means of wires under EOT-control. In the postoperative period a plaster splint was not applied. Six weeks later after wires were removed, movements in the foot joints were initiated, a complete weight bearing was allowed since the $12^{\text {th }}$ week. 
Open reposition and stabilization of fractures by means of bone plates were performed for the patients of the $3^{\text {rd }}$ clinical group with intra-articular fractures. The limb was fixed by means of Bohler frame during three days after surgery. Pain-killing, anti-edematous therapy, antibiotics, immobilization of the limb by means of a plaster splint were indicated for such patients. The patients were allowed to go on crutches since the $4^{\text {th }}$ day after surgery, graduated weight bearing on the limb was allowed since the $8^{\text {th }}$ week, and a complete one - since the $12^{\text {th }}$ week.

Results and discussion. Remote results of treatment were studied for the period from six months to two years after surgery. The results were assessed by the American Orthopedic Foot and Ankle Score (AOFAS).

The remote results of $18(85,71 \%)$ out of 21 patients from the first group showed that the results of treatment were considered to be as good (80 points by AOFAS). In $3(14,29 \%)$ patients including those 2 $(66,66 \%)$ with verified DM suppuration of the soft tissues occurred in the early postoperative period, which was eliminated in time during 10 days and did not affect the results of treatment.

32 individuals from the second clinical group after closed reposition of intra-articular fractures and wire fixation did not present early postoperative complications. 27 (84,37\%) patients received good results of treatment (76 points by AOFAS). Only $5(15,62 \%)$ individuals in $1-2$ years developed deforming arthrosis with painful syndrome (57 points). 1 (3,12\%) patients with DM who interrupted to take glucose-correcting therapy and did not consult the endocrinologist any more developed diabetic foot syndrome resulting in amputation on the level of the upper third of the leg in 2,5 years.

Among 19 patients of the third clinical group $6(31,57 \%)$ individuals developed skin necrosis in the postoperative period including those $4(66,66 \%)$ with verified DM. $4(21,05 \%)$ patients developed deforming arthrosis of the subtalar joint with pronounced pain syndrome and walking disorders, only $9(47,38 \%)$ patients demonstrated good results of treatment -76 points by AOFAS.

Therefore, the analysis of remote results of surgery performed on intra-articular fractures of the calcaneal bone in patients suffering from DM showed that the use of closed reposition under EOTcontrol and wire fixation leads to improved results of treatment and reduced inability-to-work terms.

Conclusions. 1. Among all the patients with calcaneal fractures after performed surgery $61,11 \%$ of complications occurred in patients with diabetes mellitus.

2. Closed reposition under electrical optical transducer control and wire fixation enable to decrease traumatic results of surgery and risk of complications in patients with diabetes mellitus $60.00 \%$ down.

3. Remote results of treatment of patients with intra-articular fractures of the calcaneal bone demonstrated that closed reposition and wire fixation of fractures lead to better results of treatment in $84,32 \%$ of cases as compared to bone osteosynthesis $-39,94 \%$.

\section{REFERENCES}

1. Nanynets V.Ia., Liabakh A.P. Dyferentsiina diahnostyka bolovoho syndromu v zadnomu viddili stopy u patsiientiv iz nepravylno zroshchenymy perelomamy piatkovoi kistky. Visnyk ortopedii, travmatolohii ta protezuvannia. 2016. № 2 (89). P. 58-59. [In Ukrainian].

2. Nikitin P.V. Diahnostyka ta likuvannia poshkodzhen kistok. Kyiv. - 2005. 188 p. [In Ukrainian]

3. Tokmakova A. Yu. Doronyna L.P., Strakhova H.Iu. Khronycheskye ranы у sakharnыi dyabet: sovremennaia kontseptsyia y perspektyvы konservatyvnoho lechenyia. Sakharnыi dyabet. 2010. №4. P. 6368. [In Russian].

4. Armstrong D. G. Fryckberg R. Classifying diabetic foot surgery: toward a rational definition. Diabetic Medicine. 2008. N20. P. 329-331.

5. Liabakh A.P., Omelchenko T.M., Khomych S.V., Nanynets V. Ya. Likuvannia perelomiv piatkovoi kistky ta yikh naslidkiv (ohliad literatury). Visnyk ortopedii, travmatolohii ta protezuvannia, 2012, № 3: 70-75. [In Ukrainian]

6. Jiang N. Lin Q., Diao X. Surgical versus nonsargical treatment of displaced intraarticular fracture: a metaanalisis of current evidence base Internat. Orthop. Assoc. 2012. Vol. 36, № 8. P. 1615-1622.

7. Dedov, I.I. Innovatcionnye tekhnologii v lechenii i profilaktike sakharnogo diabeta i ego oslozhnenii. Sakharnyi diabet. 2013. №3. P. 2-10. [In Russian].

8. Wagner F. W. A classification and treatment program for diabetic, neuropatic and dysvascular foot problems in THE American Academy of Ortopaedic Surgeons instructional course lectures. St. Louis: Mosby Year Book, 1979. P. 143-165.

9. World Health Organization (no authors listed). Definition and diagnosis of diabetes mellitus and intermediate hyperglycaemia: Report of a WHO/IDF consultation // WHO; IDF. 2006. - 50 p. 